\title{
QUANTUM WELL THERMOELECTRICS FOR CONVERTING WASTE HEAT TO ELECTRICITY
}

\author{
QUARTERLY TECHNICAL PROGRESS REPORT
}

\section{REPORTING PERIOD 04-01-2004 THROUGH 06-30-2004}

\author{
Submitted By \\ Hi-Z Technology, Inc. \\ 7606 Miramar Road, Suite 7400 \\ San Diego, CA 92126 \\ Prepared By \\ Saeid Ghamaty, P.I \\ Sal Marchetti, Project Controls \\ Phone (858) 695-6660 \\ FAX (858) 695-8870
}

Issued July 30, 2004 


\section{DISCLAIMER}

"This report was prepared as an account of work sponsored by an agency of the United States Government. Neither the United States Government nor any agency thereof, nor any of their employees, makes any warranty, express or implied, or assumes any legal liability or responsibility for the accuracy, completeness, or usefulness of any information, apparatus, product, or process disclosed, or represents that its use would not infringe privately owned rights. Reference herein to any specific commercial product, process, or service by trade name, trademark, manufacture, or otherwise does not necessarily constitute or imply its endorsement, recommendation, or favoring by the United States Government or any agency thereof. The views and opinions of authors expressed herein do not necessarily state or reflect those of the United States Government or any agency thereof." 


\begin{abstract}
New thermoelectric materials using Quantum Well (QW) technology are expected to increase the energy conversion efficiency to more than $25 \%$ from the present $5 \%$, which will allow for the low cost conversion of waste heat into electricity.

Hi-Z Technology, Inc. has been developing QW technology over the past six years. It will use Caterpillar, Inc., a leader in the manufacture of large scale industrial equipment, for verification and life testing of the QW films and modules.

Other members of the team are Pacific Northwest National Laboratory, who will sputter large area QW films. The Scope of Work is to develop QW materials from their present proof-of-principle technology status to a pre-production level over a proposed three year period. This work will entail fabricating the QW films through a sputtering process of $50 \mu \mathrm{m}$ thick multi layered films and depositing them on 12 inch diameter, $5 \mu \mathrm{m}$ thick Si substrates.

The goal in this project is to produce a basic 10-20 watt module that can be used to build up any size generator such as: a 5-10 kW Auxiliary Power Unit (APU), a multi kW Waste Heat Recovery Generator (WHRG) for a class 8 truck or as small as a 10-20 watt unit that would fit on a daily used wood fired stove and allow some of the estimated 2-3 billion people on earth, who have no electricity, to recharge batteries (such as a cell phone) or directly power radios, TVs, computers and other low powered devices.
\end{abstract}




\section{TABLE OF CONTENTS}

$1 \quad$ List of Graphics

2 Introduction

3 Executive Summary

4 Progress By Tasks/Experimental/Results and Discussions/Conclusions

5 Progress on the Purchase of the Sputtering Machine

6 References / Bibliography / Acronyms 


\section{LIST OF GRAPHICS}

Figure 1. Isothermal aging studies.

Figure 2. Pressure Contact Module With QW films.

Figure 3. Wire bonding

Figure 4. Isothermal aging studies of QW B4C/B9C-Si/SiGe Couple.

Figure 5. PNNL Experimental Results

Table 1. TE Properties Comparison.

Figure 6. Measured effective resistivity vs temperature

Figure 7. Measured effective Seebeck vs temperature

Figure 8. Measured effective thermal-k vs temperature

Figure 9. Measured effective efficiency of the couple

\section{INTRODUCTION}

$\mathrm{Hi}-\mathrm{Z}$ is making progress on the development of a new type of thermoelectric conversion device called Quantum Wells (QW). Hi-Z has recently measured power and efficiency demonstrating a QW couple conversion efficiency of $14 \%$, using a $11 \mu \mathrm{m}$ QW film deposited on a $5 \mu \mathrm{m}$ thick silicon substrate. The thickness of the films, area of deposition, and the method of joining $\mathrm{N}$ and $\mathrm{P}$ legs is the substance of this research and development effort.

\section{EXECUTIVE SUMMARY}

In this quarter Hi-Z started fabrication of thicker $(>11: \mathrm{m}) \mathrm{QW}$ films and also started development of joining techniques for fabricating the $\mathrm{N}$ and $\mathrm{P}$ legs into a couple. The upper operating temperature limit for these films is unknown and will be determined via the isothermal aging studies that are in progress. Fabrication of the films from the present $11 \mu \mathrm{m}$ with an efficiency $14 \%$ to the 30 $50 \mu \mathrm{m}$ range with a possible efficiency of $\sim 21 \%$, is expected to be difficult since the added layers could induce stresses that will lead to warping or cracking of the films and the Si substrate. The sputtering techniques may have to be modified to develop these much thicker films. We will be reporting on these studies in the future. The properties of the QW films that are being evaluated are Seebeck, thermal conductivity and thermal-to-electricity conversion efficiency.

\section{PROGRESS BY TASKS/EXPERIMENTAL/RESULTS AND DISCUSSION/ CONCLUSIONS}

\section{Joining $\mathbf{N}$ and $\mathbf{P}$ legs and Thermal Stability}

As was mentioned on the monthly reports, the joints are being made by silver epoxy and while this may be acceptable for low temperature service, long term low resistance stable bonds are needed for high temperature generation. Critical to this need is that each $100 \mathrm{D}$ thick layer needs to be metallurgically contacted or "wetted" to obtain the lowest possible contact resistance. With the above goal in mind, following technologies are being investigated and will be pursued: 
1. Conductive epoxies

2. Pressure contact

3. Metal spraying

4. Wire bonding

5. Conductive inks

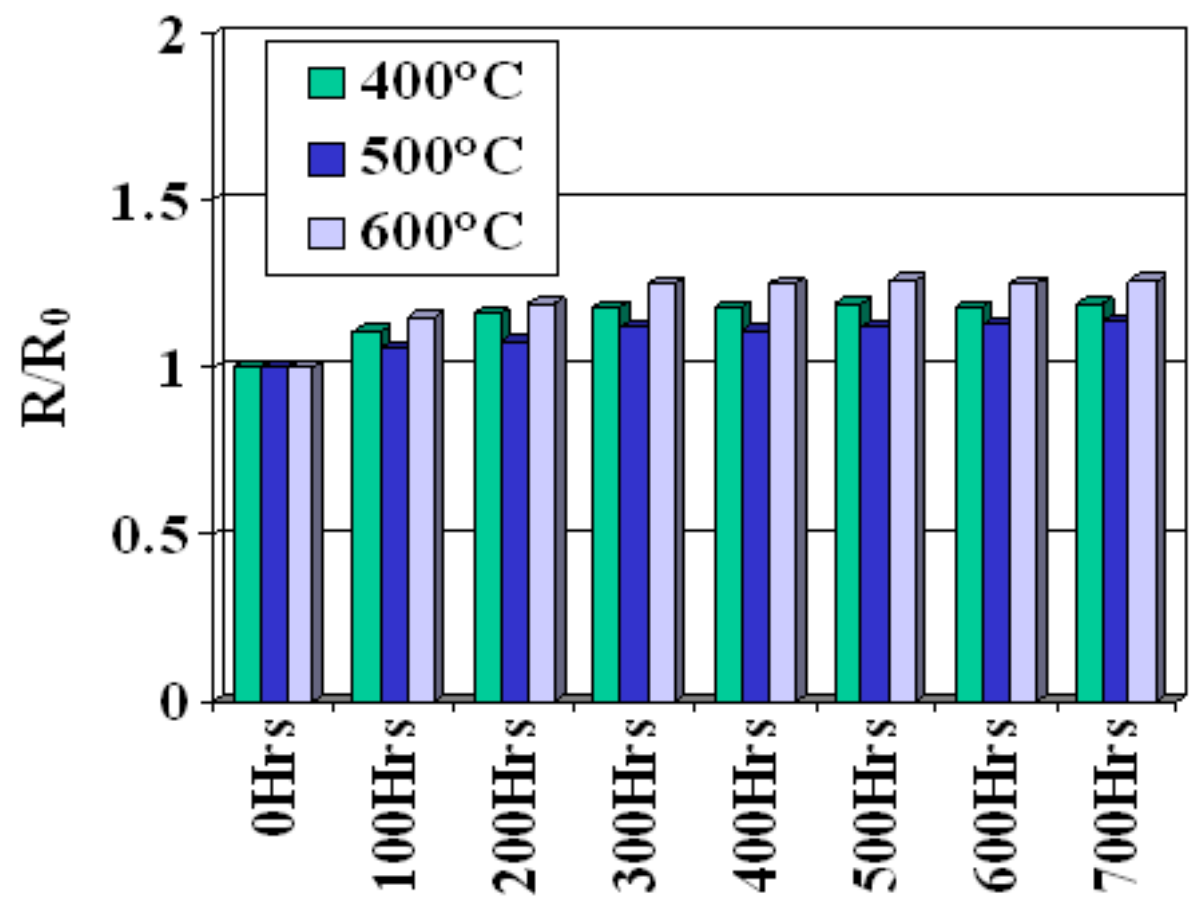

Figure 1. Isothermal aging studies. Y-axis is the resistivity ratio at various aging time. The resistance ratio includes both the resistance of the QW samples as well as the Ag conductive epoxy used to make the low resistance contact. Individual aging of the contact and the QW films will be measured after $\sim 2000 \mathrm{Hrs}$.

Developing low resistance electrical contacts to the QW materials is the primary goal for developing a stable module. The three $\mathrm{QW}$ materials, $\mathrm{Si} / \mathrm{SiGe}, \mathrm{Si} / \mathrm{SiC}$ and $\mathrm{B}_{4} \mathrm{C} / \mathrm{B}_{9} \mathrm{C}$, appear to be thermally stable materials and isothermal tests at 400,500 , and $600^{\circ} \mathrm{C}$ are underway indicating little or no change in electrical properties with time while their respective compatibilities are discussed below. Figure 1 shows this isothermal test.

In earlier compatibility tests at RCA with SiGe alloys and some of the candidate materials, $\mathrm{MoSi}_{2}$ was shown to be very stable with $\mathrm{SiGe}$ even at $1000^{\circ} \mathrm{C}$. Also, some silicides showed promise at much lower temperatures like $500-600^{\circ} \mathrm{C}$. Most metals tend to form silicides that have acceptable conductivities. For example, Ti, Pd and Pt are used extensively with Solar cells and form stable conducive silicides. It is then the thermal expansion compatibility of the metal silicide with the QW material that is critical, especially as the temperature is increased and more silicide forms at the interface. If the silicide can match the QW substrate in thermal expansion there is good reason to expect good compatibility. W, Mo, Ni and Ni Aluminides, which can be thermally sprayed on $\mathrm{Si}$, reportedly exhibit a low contact resistance and will be evaluated next. Au and Ag also form low 
contact resistances with Si but their low melting eutectics (Au-Si M.P. $363^{\circ} \mathrm{C}$, Ag-Si M.P. $835^{\circ} \mathrm{C}$ ) may preclude long term use at elevated temperatures.

With the Si/SiC QW material the compatibility should be improved over $\mathrm{Si} / \mathrm{SiGe}$ since $\mathrm{SiC}$ is a very stable compound. Thus the same materials that are compatible with $\mathrm{Si} / \mathrm{SiGe}$ should be compatible with $\mathrm{Si} / \mathrm{SiC}$. The $\mathrm{B}_{4} \mathrm{C} / \mathrm{B}_{9} \mathrm{C}$ alloys are known to form a low contact resistance with $\mathrm{Au}$ and carbon. Other materials no doubt form low contact resistance with $\mathrm{B}_{4} \mathrm{C} / \mathrm{B}_{9} \mathrm{C}$ but need to be evaluated.

Common to all these materials compatibilities is the need to develop low resistance ohmic contacts and to match their thermal expansions so interfacial resistances are not developed. In some of the contacting approaches described below allowances are made to relieve/accommodate the strains that may develop and maintain low resistance joints.

\section{Pressure Contacts}

By first metallizing the hot and cold junctions of the three QW material combinations $\mathrm{Si} / \mathrm{SiGe}$, $\mathrm{Si} / \mathrm{SiC}$, and $\mathrm{B}_{4} \mathrm{C} / \mathrm{B}_{9} \mathrm{C}$, it should be possible to assemble a module that can obtain a low contact resistance and also accommodate the strains due to high temperature operation, thermal cycling, etc. Shown in Figure 2 is a strawman design using pressure contacts. In this approach, the QW $\mathrm{N} \& \mathrm{P}$ materials for an eggcrate loading are coated on their cold and hot ends with metals such as $\mathrm{Ni}$ and/or Mo. The coating initially will be a few microns thick and deposited by sputtering for enhanced adherence. It will then be built up to 2-3 mils by high speed evaporation. The metallized $\mathrm{N} \& \mathrm{P}$ legs will be loaded in the eggcrate and a soft metal pad ( $\sim 0.020$ in. thick) such as Ag will be placed in contact. A compliant felt metal on the cold side will assure the Ag stays in contact with the QW metallization.

The hot and cold side

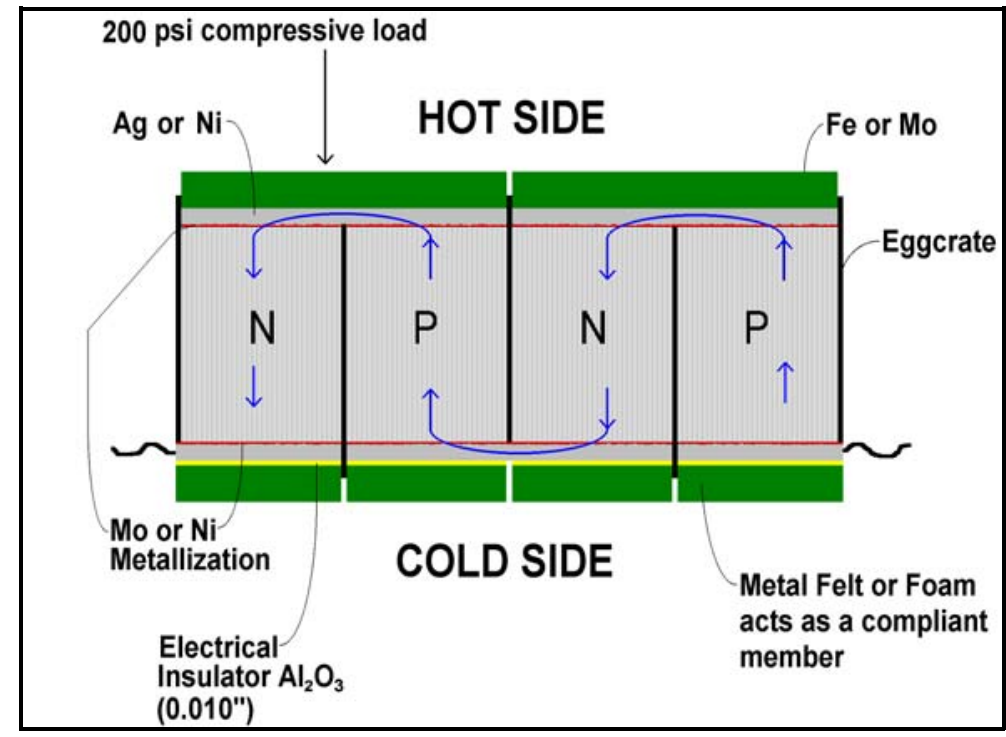

Figure 2. Pressure Contact Module With QW films. All N \& P films in each element in contact with each other. designs are the same (except for the compliant pad and electrical insulator) but can be altered to accommodate various materials. Since most thermoelectric module applications use the modules in compression to obtain good heat transfer, this fabrication approach allows this compression force to be used as an advantage.

For the two N \& P couples fabricated and evaluated and shown in Figure 2, the N and P legs were first metallized on the ends with Au. They were then held in compression with each other and conducive epoxy used for holding the two legs together as shown in Figure 2. While this approach was useful for this couple efficiency test, it is not suitable for fabricating modules for long term high temperature operation. 


\section{Metal Spraying}

Just about any metal can be sprayed in an inert atmosphere or air. In air, however, the QW materials oxidize as the hot metal makes contact with the surface causing high contact resistances. This effect is not seen with the $\mathrm{Bi}_{2} \mathrm{Te}_{3}$ based alloys. Therefore, the initial metal contact to the QW surfaces could be performed in an inert atmosphere with thermal spray or with sputtering/evaporation processes to build up a layer to 0.001-0.003 in. thick. After an annealing treatment at $\sim 400^{\circ} \mathrm{C}$ ( similar to forming metal contacts on Si solar cells), the metal bond strength to the QW will be enhanced and the contact resistance lowered. On top of this surface it should be possible to deposit metals in air/inert gas such as $\mathrm{Al}, \mathrm{W}, \mathrm{Mo}, \mathrm{Zn}, \mathrm{Ni}$, the $\mathrm{Ni}$ Aluminides and many other materials such as $\mathrm{MoSi}_{2}$ noted above which has a CTE very close to $\mathrm{Si}$ and $\mathrm{SiC}$. In the thermal spraying of the $\mathrm{Bi}_{2} \mathrm{Te}_{3}$ thermoelectric modules it has been observed that large differences in CTE can be accommodated probably because the spray materials are deposited on surfaces that are typically no higher than $\sim 100^{\circ} \mathrm{C}$ and are immediately quenched and the materials deposited are not $100 \%$ dense. Further the materials in the module (the liquid crystal eggcrate material and the Al contacts) may relax to relieve thermally induced stresses. Some of this self accommodation may also be obtained with the QW materials. Thermal spraying of the QW films has just started and the initial result will be reported in the next monthly report.

\section{Wire/Ribbon Bonding}

Wire/ribbon bonding will require a metallization of the QW surfaces. A description of the process is shown in Figure $3^{\odot}$ (from Kulicke \& Soffa). This process is in very wide application in the electronics industry and will allow the following:

a. Many wires/ribbons can be bonded between the N \& P legs in a short time period.

b. The wire ribbon need not be taught so the electrical contacts can accommodate thermally developed stresses.

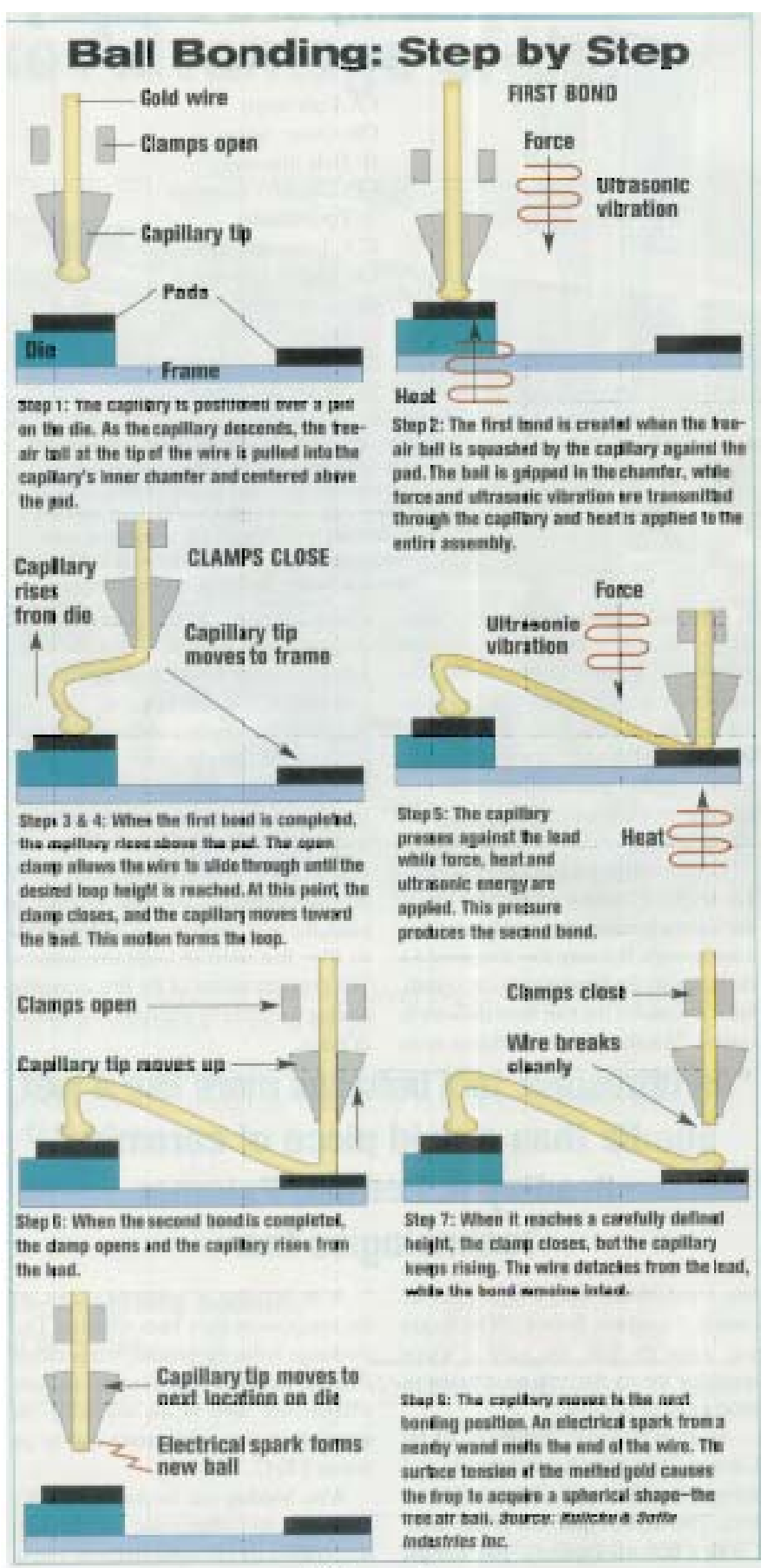

Figure 3 
c. This approach can be combined with the pressure contact approach as previously shown in Figure 2 for added reliability and to produce a surface that is flat for good heat transfer.

Wire bonding of the QW films has just started and the initial result will be reported in the next monthly report.

\section{Thermal Stability of Si/SiGe $-\mathrm{B}_{4} \mathrm{C} / \mathrm{B}_{9} \mathrm{C}$ Couple}

As was mentioned on the previous reports, the joints are being made by silver epoxy and while this may be acceptable for low temperature service, long term low resistance stable bonds are needed for high temperature generation. Critical to this need is that each $100 \mathrm{D}$ thick layer needs to be metallurgically contacted or "wetted" to obtain the lowest possible contact resistance.

Developing low resistance electrical contacts to the $\mathrm{QW}$ materials of $\mathrm{Si} / \mathrm{SiGe}$ to $\mathrm{B}_{4} \mathrm{C} / \mathrm{B}_{9} \mathrm{C}$ at 400,500 , and $600^{\circ} \mathrm{C}$ are underway indicating little or no change in total electrical properties with time while their respective compatibilities are discussed below. Figure 4 shows the latest isothermal data for couples. The resistance ratio shown in the figure includes both the resistance of the both QW Si/SiGe plus $\mathrm{B}_{4} \mathrm{C} / \mathrm{B}_{9} \mathrm{C}$ as well as the $\mathrm{Ag}$ conductive epoxy used to make the low resistance contact. Individual aging of the contact and the QW films will be measured after $\sim 2000 \mathrm{Hrs}$.

Sample Evaluation by Hi-Z, PNNL and NRL

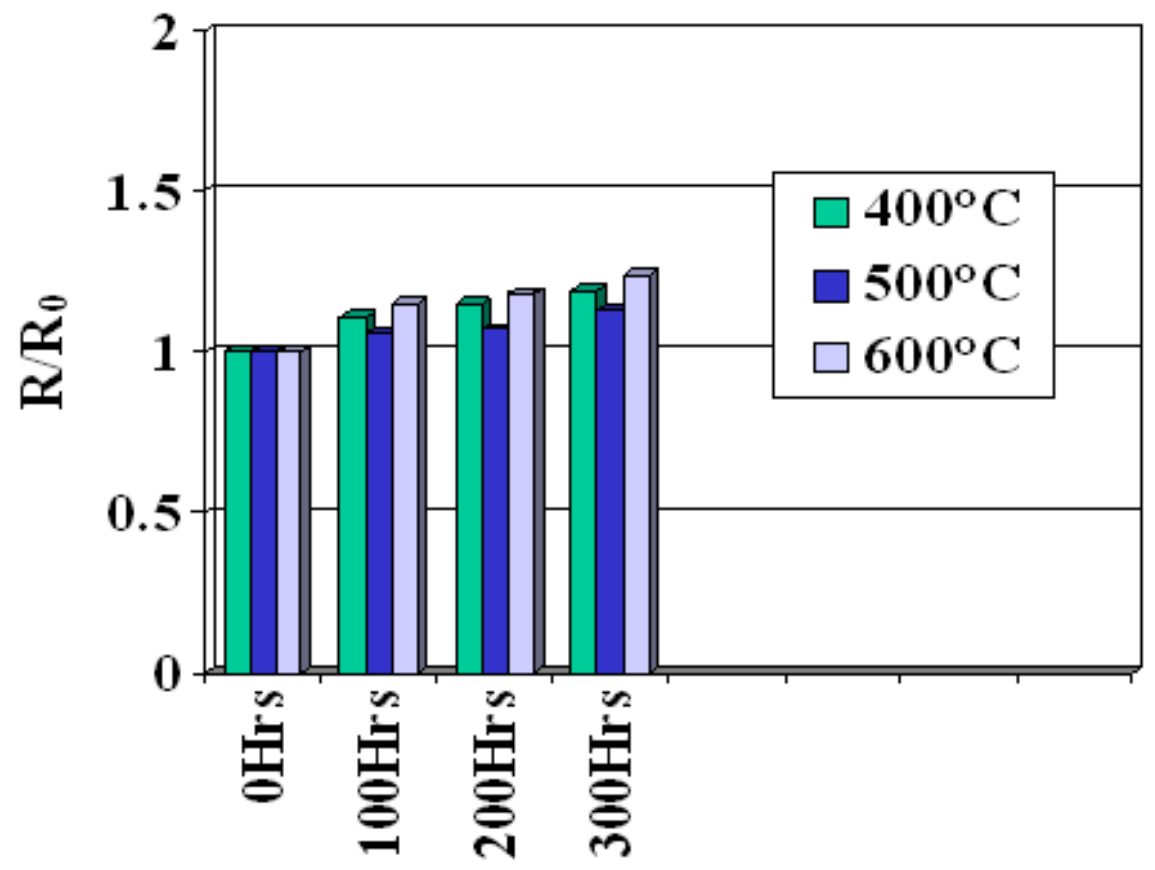

Figure 4. Isothermal aging studies of $\mathrm{Si} / \mathrm{SiGe}-\mathrm{B}_{4} \mathrm{C} / \mathrm{B}_{9} \mathrm{C}$ couple. Y-axis is the resistivity ratio at various aging time. The resistance ratio includes both the resistance of the QW Si/SiGe plus $\mathrm{B}_{4} \mathrm{C} / \mathrm{B}_{9} \mathrm{C}$ samples as well as the Ag conductive epoxy used to make the low resistance contact. Individual aging of the contact and the QW films will be measured after $\sim 2000 \mathrm{Hrs}$. 
Pacific Northwest National Laboratory (PNNL) with funding from the DOE has fabricated and measured $\mathrm{B}_{4} \mathrm{C} / \mathrm{B}_{9} \mathrm{C}$ and $\mathrm{Si} / \mathrm{SiGe}$ samples. These samples were fabricated in a similar way as the Hi-Z samples. The measured resistivity and Seebeck coefficient (done at PNNL) shows similar values as the Hi-Z samples. The PNNL results are shown in Figure 5 and are also listed in Table 1.

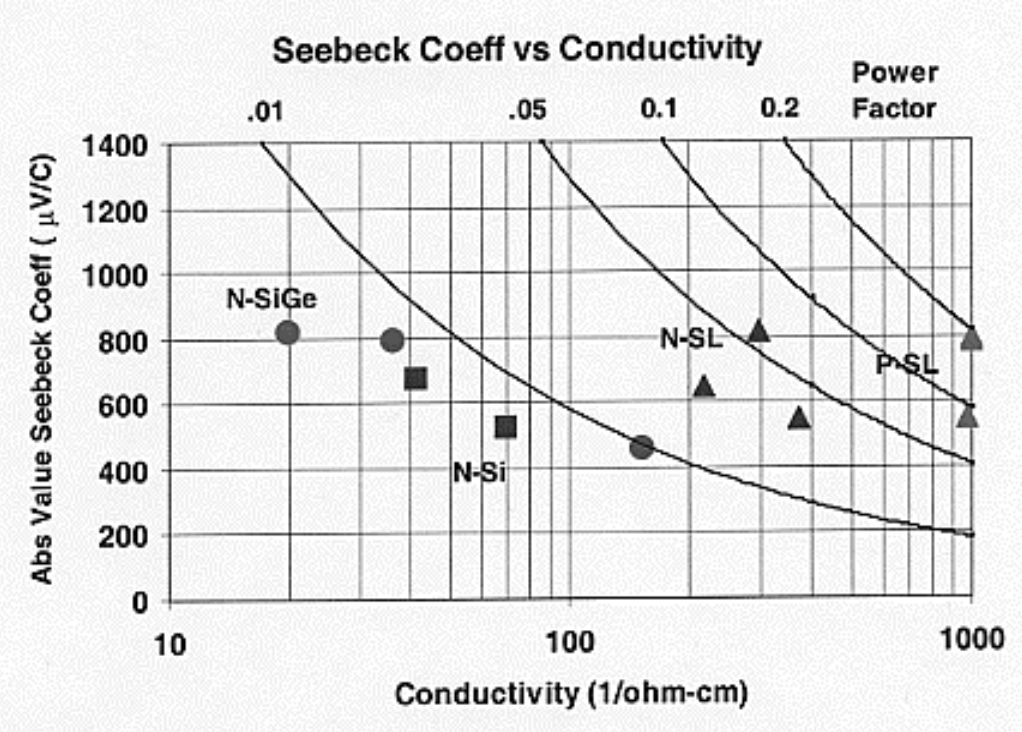

Figure 5. PNNL Experimental Results

Table 1. TE Properties Comparison. The resistivity (D) and Seebeck (") were measured at the noted institutes but the thermal conductivity was only measured at $\mathrm{Hi}-\mathrm{Z}$

\begin{tabular}{|c|c|c|c|c|c|c|}
\hline $\begin{array}{c}\text { Sample } \\
\text { Composition } \\
\end{array}$ & $\begin{array}{c}\text { Sample } \\
\text { ID }\end{array}$ & $\begin{array}{c}\text { Fabricated } \\
@\end{array}$ & $\begin{array}{c}\text { Measured } \\
@\end{array}$ & $\begin{array}{c}\text { " } 2 / \mathrm{D} @ 25^{\circ} \mathrm{C} \\
(\mu \mathrm{W} / \mathrm{cm}-\mathrm{K}) \\
\end{array}$ & $\begin{array}{r}\mathrm{ZT} @ \\
25^{\circ} \mathrm{C} \\
\end{array}$ & $\begin{array}{l}\text { ZT @ } \\
150^{\circ} \mathrm{C} \\
\end{array}$ \\
\hline $\mathrm{Si} / \mathrm{SiGe}$ & $\begin{array}{l}\text { HZ062 } \\
\text { HZ062 } \\
\text { 2BK-S } \\
\text { 2BK-2 }\end{array}$ & $\begin{array}{l}\mathrm{Hi}-\mathrm{Z} \\
\mathrm{Hi}-\mathrm{Z} \\
\text { PNNL } \\
\text { PNNL }\end{array}$ & $\begin{array}{c}\mathrm{Hi}-\mathrm{Z} \\
\text { NRL } \\
\text { PNNL } \\
\text { Hi-Z }\end{array}$ & $\begin{array}{l}710 \\
605 \\
690 \\
686\end{array}$ & $\begin{array}{l}2.1 \\
1.8 \\
2.0 \\
2.0\end{array}$ & $\begin{array}{c}3.0 \\
- \\
- \\
2.6\end{array}$ \\
\hline $\mathrm{B}_{4} \mathrm{C} / \mathrm{B}_{9} \mathrm{C}$ & $\begin{array}{l}\text { HZ102 } \\
\text { HZ102 } \\
1 \mathrm{~W}-\mathrm{PB} \\
1 \mathrm{~W}-\mathrm{PB}\end{array}$ & $\begin{array}{l}\mathrm{Hi}-\mathrm{Z} \\
\mathrm{Hi}-\mathrm{Z} \\
\text { PNNL } \\
\text { PNNL }\end{array}$ & $\begin{array}{c}\text { Hi-Z } \\
\text { NRL } \\
\text { Hi-Z } \\
\text { PNNL }\end{array}$ & $\begin{array}{l}920 \\
891 \\
860 \\
822\end{array}$ & $\begin{array}{l}2.9 \\
2.8 \\
2.7 \\
2.6\end{array}$ & $\begin{array}{c}4.1 \\
- \\
3.8 \\
--\end{array}$ \\
\hline $\mathrm{Bi}_{2} \mathrm{Te}_{3}$ alloy & - & - & Published & $\sim 80$ & $\sim 1$ & $\sim 1$ \\
\hline
\end{tabular}

Samples fabricated by Hi-Z were also measured by the Naval Research Laboratory (NRL), the results are shown in Table 1. The results are also similar to those generated by Hi-Z and PNNL. Table 1 summarizes these comparisons and the three parties and they show very good agreement and very encouraging thermoelectric performance. As shown in Table 1, the $\mathrm{Bi}_{2} \mathrm{Te}_{3}$ alloys have a value of ZT of about 1 . These results are consistence with the previously reported data by Hi-Z shown below. 
The thermoelectric properties, resistivity $(\rho)$, Seebeck coefficient $(\alpha)$ as well as thermal conductivity ( $\kappa)$ of the $11 \mu \mathrm{m}$ thick films $\mathrm{N}$ and P materials that comprise the couple were measured. The results are shown in the Figures 6,7 and 8. All the properties were measured experimentally for both the film and substrate together, and represent an "effective", film+substrate, or composite, with no data correction. In other words, the properties of the $5 \mu \mathrm{m}$ thick substrate have not been subtracted out of the data shown in Fig. 6,7 and 8. All the properties were measured on the same sample except for the thermal conductivity, which was measured on a different sample but from the same batch, using the three omega method.

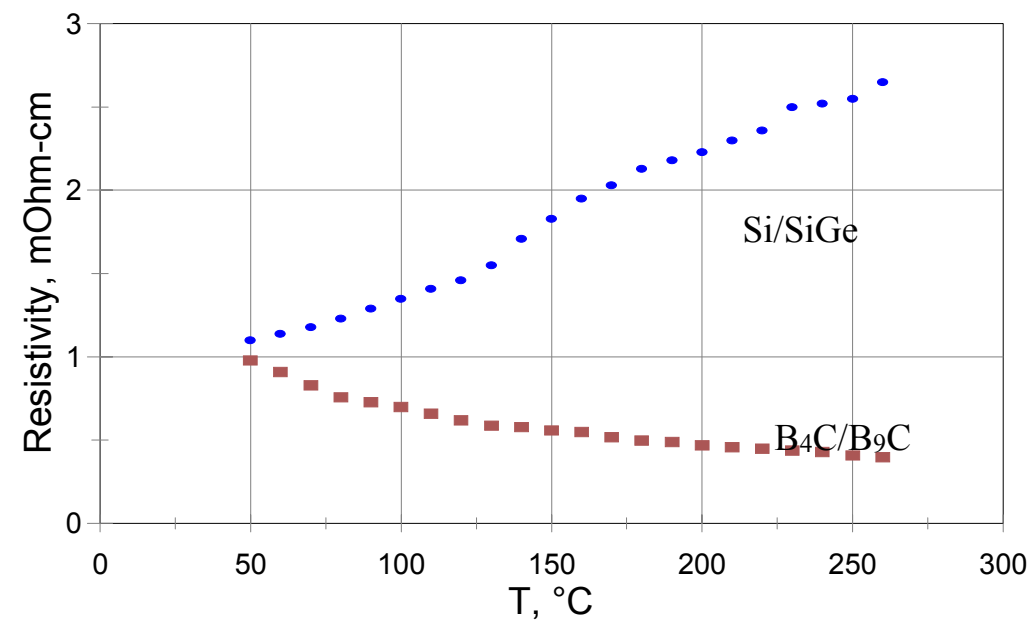

Figure 6. Measured Effective Resistivity Vs Temperature.

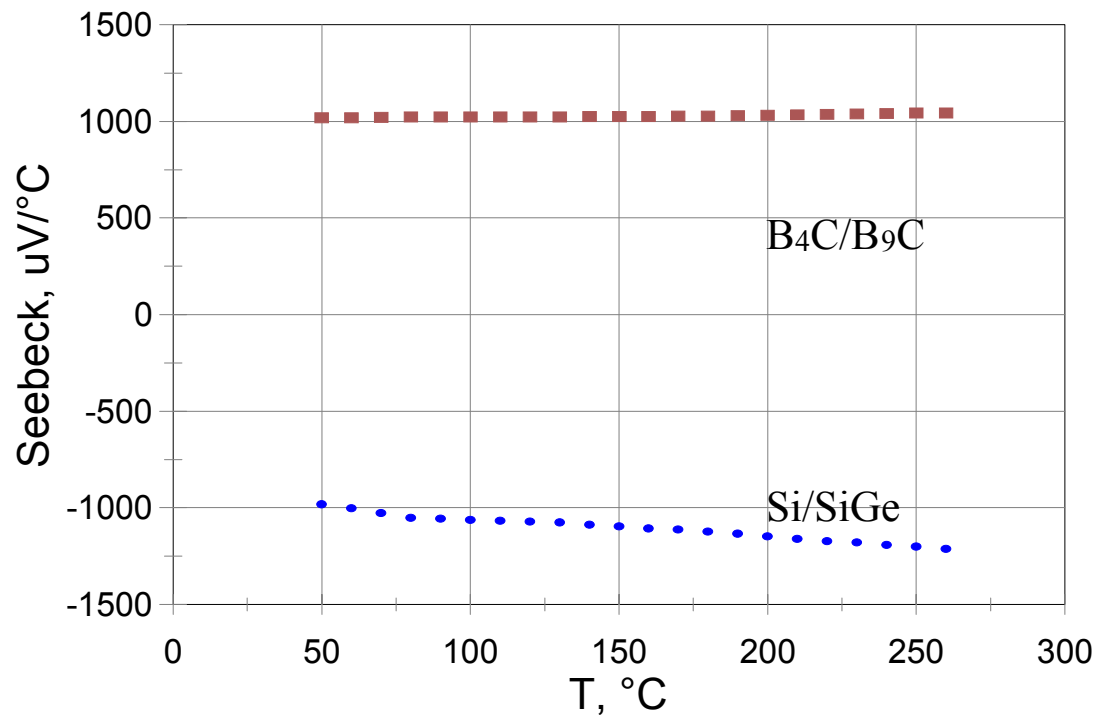

Figure 7. Measured Effective Seebeck Vs Temperature 


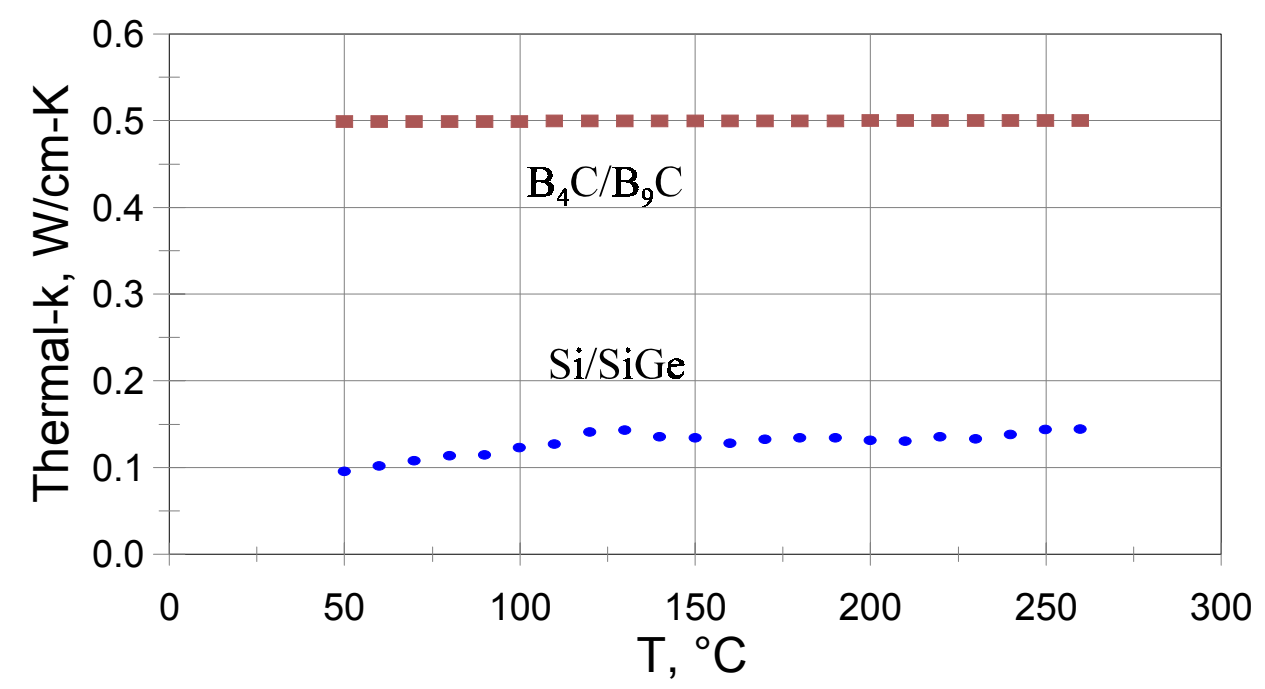

Figure 8. Measured Effective Thermal-k Vs Temperature

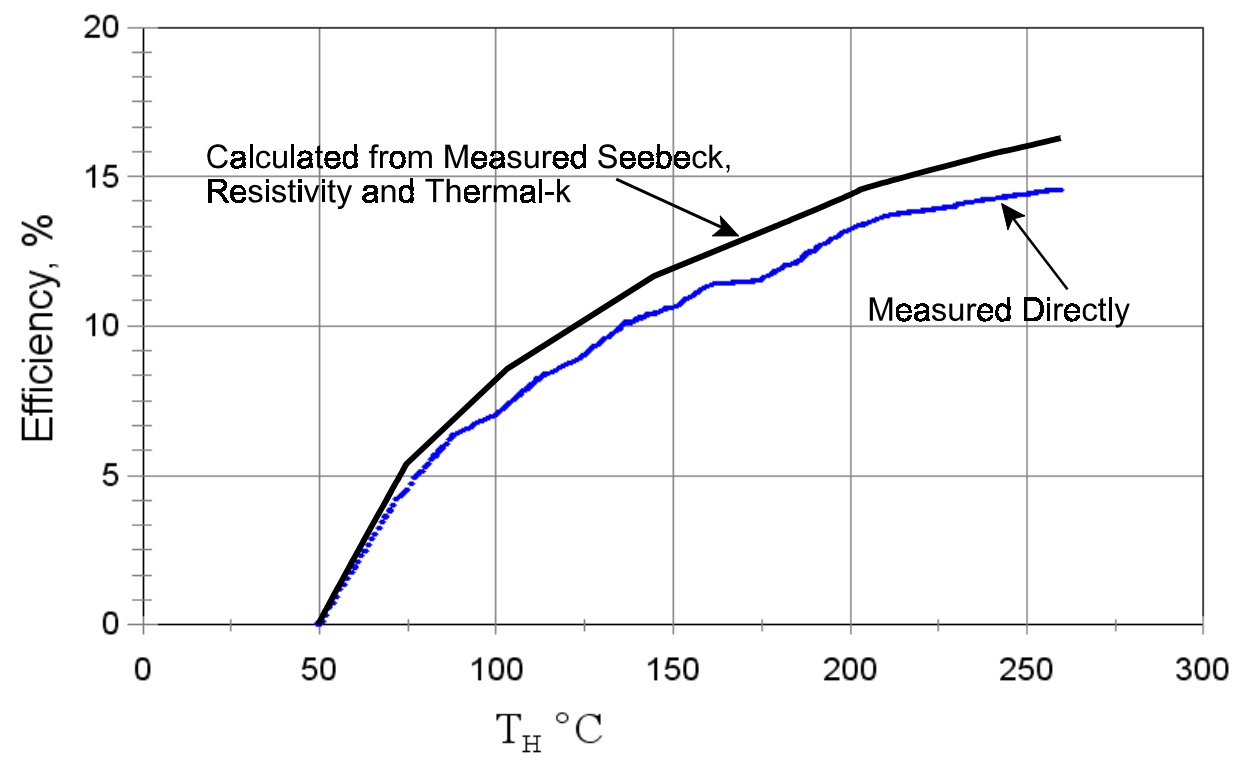

Figure 9. QW Couple Efficiency Vs Temperature

These measured properties, were then used to calculate the efficiency of the couple, and the result is shown in Figure 9. This efficiency calculation is in close agreement with the direct efficiency measurement presented before and is also shown in the Figure 9.

\section{PROGRESS ON THE PURCHASE OF THE SPUTTERING MACHINE}

The purchase order for the 34" sputtering machine was placed December 1, 2003. Progress payments totaling $\$ 161,150$ have been made. A third progress payment in the amount of $\$ 128,920$ is expected to be made at a time of shop check-out in the fabricator's shop on or around August 7, 
2004. The final payment of $\$ 32,230$ will be made upon operational checkout of the new sputtering machine in Hi-Z's facilities. Delivery of the machine is expected in late August, 2004. This is approximately 3 months behind the original schedule. DOE ORO's payment of the agreed $\$ 100,000$ share of the $\$ 322,300$ total cost of the machine was received in the first week of January. NETL's agreed share of $\$ 105,000$ was received January $16^{\text {th }}$. NASA's agreed share of $\$ 90,000$ was received April 8, 2004 NAVSEA's share amounting to $\$ 27,300$ has been billed to them in advance of the operational checkout and the final payment. The government funds awaiting the next disbursement to the fabricator are being held in a special interest-bearing money market account restricted to government funds. Hi-Z, on June 7, 2004, issued a Procedure of Control of Government Property following the requirements of 10CFR 600.130 through 10CFR 600.137. All the organizations participating in the purchase of the sputtering machine have received a copy.

\section{REFERENCES/BIBLIOGRAPHYIACRONYMS}

Any references and bibliography are as submitted in the proposal, pages 24 and 25. Acronyms and abbreviations are explained the first time they appear in the text. 